ROCZNIKI TEOLOGICZNE

Tom LXVII, zeszyt $4-2020$

DOI: http://dx.doi.org/10.18290/rt20674-4

KS. KRZYSZTOF DALECKI

\title{
SŁUGA BOŻY ANTONI HENRYK SZUMAN - TERCJARZ FRANCISZKAŃSKI
}

\author{
SERVANT OF GOD ANTONI HENRYK SZUMAN - FRANCISCAN TERTIARY
}

\begin{abstract}
This article concerns Msgr. Antoni Henryk Szuman, who leads the second group of martyrs from the diocese of Pelplin in the current beatification process. It attempts to sketch his activity as a Franciscan tertiary, which until now remains the least well-know element of his life. The article starts with a general picture of Polish Franciscan tertiaries and their activities and proceeds to an analysis of functions and works of Szuman in the Third Ordere.
\end{abstract}

Key words: diocese of Pelplin; $2^{\text {nd }}$ group of Polish martyrs; beatification process; Szuman; Third Order of St. Francis.

Dla dziejów diecezji pelplińskiej, dawnej chełmińskiej, postać Sługi Bożego ks. prałata Antoniego Henryka Szumana ${ }^{1}$ jest bardzo ważna. Przewodniczy on

Ks. mgr KRZYSZTOF DALECKI - doktorant II roku Historii Kościoła w Instytucie Nauk Teologicznych KUL; adres do korepondencji - e-mail: xkrzysztofdalecki@gmail.com; ORCID: https://orcid.org/0000-0002-1810-0443

${ }^{1}$ Antoni Henryk Szuman ur. 13.06. 1882 roku w Toruniu, w rodzinie Leona i Eugenii z Gumpertów. Tam uczęszczał do miejscowego Klasycznego Gimnazjum. W Toruniu pełnił funkcję przewodniczącego tajnej organizacji filomackiej, kształtując wśród młodzieży polską świadomość narodową na konspiracyjnych spotkaniach w domu Szumanów. Za działalność tę był sądzony w słynnym procesie filomatów pomorskich w Toruniu w roku 1901. Po egzaminie dojrzałości (1904) wstąpił do WSD w Pelplinie, gdzie stał na czele ruchu narodowo-polskiego wśród kleryków. 23.02. 1908 r. otrzymał święcenia kapłańskie. Po 3 latach posługi duszpasterskiej rozpoczął studia na UJ w Krakowie, gdzie współpracował ze Związkiem Młodzieży Przemysłowej. Następnie znów posłany został do duszpasterstwa. Pełnił wtedy posługę wikariusza w Nidzicy oraz we Wielu. W roku 1915 został proboszczem w Trzebczu, następnie od roku 1920 w Nawrze, gdzie bardziej ceniono go za wspaniałą osobowość niż umiejętność głoszenia słowa. Brał żywy udział w wielu organizacjach polskich (m.in. Powiatowa Rada Ludowa w Chełmnie, Komisja Oświatowa, Towarzystwo Naukowe w Toruniu, Komitet Towarzystwa Czytelni Ludowych, Rada Opieki Społecznej w Warszawie, Katolickie Stowarzyszenie Piotra Skargi). Dwa nurty pracy, ja- 
bowiem II grupie polskich męczenników okresu II wojny światowej w trwającym obecnie procesie beatyfikacyjnym, którego oficjalny tytuł brzmi: „Sprawa Pelplińska o beatyfikacji, czyli deklaracji męczeństwa Sług Bożych Henryka Szumana, kapłana diecezjalnego i 121 towarzyszy, kapłanów diecezjalnych, zakonników i zakonnic oraz wiernych świeckich mężczyzn i kobiet, którzy, jak się mniema, zostali zabici z powodu nienawiści do wiary"2. Na etapie diecezjalnym sprawa ta zakończyła się 24 maja 2011 r. $^{3}$. Wspomniany fakt nie jest jednak jedynym, świadczącym o wyjątkowości tego kapłana. Ks. Szuman ciągle jest żywy w pamięci mieszkańców Starogardu Gdańskiego, nie tylko dzięki staraniom miejscowych kapłanów, ale także innych społeczników, którzy uczcili go pamiątkowymi tablicami w tamtejszych kościołach pw. św. Mateusza oraz św. Wojciecha, a także nadali jego imię jednej z ulic tego miasta ${ }^{4}$.

\section{PRZESTRZENIE DZIAŁALNOŚCI SPOŁECZNEJ KS. HENRYKA SZUMANA}

Przeglądając literaturę dotyczącą życia pelplińskiego Sługi Bożego, bez problemu można znaleźć w niej artykuły, a nawet książki poświęcone jego pracy na rzecz sierot wojennych, która najpiękniej przejawiła się w działalności, prowadzonego przez ks. Szumana, Pomorskiego Towarzystwa Opieki nad Dziećmi. Tą przestrzenią jego pracy bardzo szczegółowo zajął się Wiesław Theiss ${ }^{5}$. Biografem życia Sługi Bożego był także ks. Jan Sajewicz ${ }^{6}$

kim w całości poświęcił się ten kapłan, to pomoc dzieciom, zwłaszcza sierotom (był założycielem Pomorskiego Towarzystwa Opieki nad Dziećmi), a także walka z alkoholizmem. Jako proboszcz w Starogardzie Gdańskim przyczynił się znacznie do rozwoju „Caritasu”, a także wybudował kościół p.w. św. Wojciecha. Ojciec św. Pius XI obdarzył go godnością prałata, natomiast rząd polski przyznał mu Order „Polonia Restituta”. Zginął 2.10.1939 r. rozstrzelany przed wejściem do kościoła w Fordonie. W 1994 roku rozpoczęto jego proces beatyfikacyjny. Zob. H. Mross, Antoni Henryk Szuman, w: Stownik biograficzny kapłanów diecezji chelmińskiej wyświęconych w latach 1821-1920, Bernardinum, Pelplin 1995, s. 324-325.

${ }^{2}$ W. Mazurowski, Ksiadz Antoni Henryk Szuman ze Starogardu Gdańskiego, „Pielgrzym” 15(2004), nr 12, s. 9.

${ }^{3}$ https://ekai.pl/pelplin-maja-zakonczenie-etapu-polskiego-procesu-beatyfikacyjnego-ii-grupy -meczennikow-ii-wojny-swiatowej/ (20.10.2019).

${ }^{4}$ K. DALECKI, Pelpliński Stuga Boży Antoni Henryk Szuman i jego walka na polu społecznego problemu alkoholizmu w okresie lat międzywojennych, „Studia Pelplińskie” 52(2018), s. 95.

${ }^{5}$ W. Theiss, Troska i nadzieja. Działalność społeczno-wychowawcza ks. Henryka Szumana na Pomorzu w latach 1908-1939, Wydawnictwo Adam Marszałek, Torun 2012; TENŻE, Społeczno-wychowawcza działalność ks. Henryka Szumana, w: Katolicka a liberalna myśl wychowawcza 
wychowanek ks. Szumana, który w swojej książce Głos maja sieroty, nawiązując do wspomnianej działalności na rzecz osieroconych dzieci, opisał także pracę redaktorską tego kapłana społecznika, która również w znacznej części poświęcona była najmłodszym. Tą aktywnością pelplińskiego kandydata na ołtarze od strony naukowej zajęła się także Izabela Krasińska ${ }^{7}$. Sam ks. Szuman szereg swoich artykułów, także tych publikowanych na łamach prasy dziecięcej, poświęcał problemowi alkoholizmu. Uważał go za „największą klęskę społeczną”8 oraz „klątwę dziejów Polski”". Artykuły na ten temat publikował on m.in. w takich pismach, jak: „Pielgrzym”, „Miesięcznik Diecezji Chełmińskiej”, „Nasz Przewodnik”, „Mały Światek”, „Wiadomości dla Duchowieństwa”, „Wiadomości Tercjarskie”, „Przyjaciel Trzeźwości”, „Ku wyżynom”, „Szlakiem wieszcza”, czy „Świt”. Myśl trzeźwościowa Sługi Bożego jest więc również mocno rozpowszechniona i znana. Dobrze opisał ją m.in. ks. Bogusław Głodowski ${ }^{10}$.

Wskazane wyżej aspekty działalności ks. Szumana omawiali również historycy zajmujący się dziejami kościoła pelplińskiego, dawniej chełmińskiego. Należy tu wymienić m.in.: Kazimierza Dąbrowskiego ${ }^{11}$, Henryka Mrossa ${ }^{12}$, Jana Walkusza ${ }^{13}$, czy Ryszarda Szwocha ${ }^{14}$. Można więc przyjąć, że wspo-

w Polsce w latach 1918-1939, red. E. Walewander, Towarzystwo Naukowe KUL, Lublin 2000, por: TENŻE: Pomorskie Towarzystwo Opieki Nad Dziećmi (1918-1948) Zarys działalności, „Kultura i Edukacja" 4(1994), s. 63-76; TENŻE, Pomorskie Towarzystwo Opieki Nad Dziećmi 19181948, „Rozprawy z Dziejów Oświaty” 36(1994), s. 173-191.

${ }^{6}$ J. SAJEwicz, Głos maja sieroty. Życie $i$ działalność wielkiego opiekuna sierot ks. prałata Antoniego Henryka Szumana proboszcza starogardzkiego zamordowanego w Fordonie w 1939 r., Veritas, Londyn 1985.

${ }^{7}$ I. KRASIŃSKA, Działalność redakcyjno-wychowawcza ks. Henryka Antoniego Szumana na rzecz najmłodszych odbiorców. Na przykładzie „Naszego Przewodnika” (1913-1919), w: Działalność instytucji wydawniczych na rzecz oświaty $i$ edukacji $w$ XIX $i$ XX wieku, red. I. Michalska, G. Michalski, Wydawnictwo Uniwersytetu Łódzkiego, Łódź 2014, s. 299-318.

${ }^{8}$ H. Szuman, O tzw. umiarkowanem piciu, „Pielgrzym” 35(1913), nr 132, s. 1.

${ }^{9}$ H. Szuman, Dlaczego i jak powinien tercjarz walczyć z alkoholizmem, „Wiadomości Tercjarskie" 1938 , nr 35, s. 350.

${ }^{10}$ B. GŁodowsKi, O ruchu trzeźwościowym $w$ diecezji chelmińskiej $w$ latach 1848-1939, Instytut Kaszubski, Gdańsk 2016.

${ }^{11}$ K. DĄBrowski, Ksiądz prałat Henryk Antonii Szuman życie i działalność, „Studia Pelplińskie" 11(1976), s. 43-55.

${ }^{12}$ H. Mross, Stownik biograficzny kapłanów diecezji chetmińskiej wyświęconych $w$ latach 1821-1920, Bernardinum, Pelplin 1995, s. 324-325.

${ }^{13}$ J. WalkuSz, Pozaduszpasterska działalność ks. Antoniego Henryka Szumana, „Męczennicy. Biuletyn informacyjny Postulacji Procesu Beatyfikacyjnego II Grupy Polskich Męczenników z okresu II wojny światowej” 2004, nr 1, s. 19-25; TENŻE, Duchowieństwo katolickie diecezji chetmińskiej 1918-1939, Wydawnictwo Diecezjalne, Pelplin 1992. 
mniane aktywności społeczne pelplińskiego kandydata na ołtarze, a więc praca na rzecz sierot wojennych - również ta redaktorska, a także walka z szerzącą się w okresie międzywojennym plagą alkoholizmu, są już dobrze znane.

Niewiele natomiast napisano do tej pory na temat działalności ks. prałata Antoniego Henryka Szumana w Trzecim Zakonie Świętego Franciszka z Asyżu. Główną przyczyną takiego stanu rzeczy jest zapewne niewielka ilość źródeł dotyczących tego zagadnienia. Do tej pory badaniem tercjarskiej aktywności proboszcza ze Starogardu Gdańskiego zajął się szerzej jedynie Mirosław Kuczkowski ${ }^{15}$, historyk, którego zainteresowania dotyczą dziejów franciszkanizmu. Pomorskiego kapłana wspomniał on najpierw w swojej pracy dotyczącej międzywojennych losów Trzeciego Zakonu na ziemiach polskich ${ }^{16}$, następnie pisał o nim na łamach „Głosu św. Franciszka”" ${ }^{17}$, w roku 2010 oraz w swojej książce Tercjarze św. Franciszka z Asyżu ${ }^{18}$ z roku 2014. Można więc postawić tezę, że tercjarska działalność ks. prałata Antoniego Henryka Szumana jest wciąż przestrzenią nie do końca odkrytą.

\section{TERCJARSTWO W OGÓLNOŚCI}

Aby dobrze zrozumieć myśl wiodącą, zawartą w tytule artykułu, należy najpierw ogólnie zarysować samo zagadnienie tercjarstwa. „Ruch franciszkański w historii Kościoła był i jest nadal jednym z większych ruchów charyzmatycznych"19. Trzeci Zakon Świętego Franciszka z Asyżu, obecnie zwany Franciszkańskim Zakonem Świeckich, można określić jako stowarzyszenie kościelne chrześcijan - katolików, którzy żyjąc w świecie, poddają się pod kierownictwo duchowe Pierwszego Zakonu Franciszkańskiego. Według duchowości franciszkańskiej dążą oni do chrześcijańskiej doskonałości, w sposób odpowiadający życiu świeckiemu, ale podlegający regule św. Franciszka

\footnotetext{
${ }^{14}$ R. SzWoch, Stuga Boży ks. prałat Antonii Henryk Szuman, „Męczennicy”, s. 13-18; TENŻE, Świadectwo życia i działalność ks. Henryka Szumana, „Pomorze” 1987, nr 4, s. 39-41.

${ }^{15}$ Mirosław Marek Kuczkowski - dr nauk teologicznych w zakresie historii Kościoła, franciszkanin świecki.

${ }^{16}$ M. KuCZKowski, Dzieje Trzeciego Zakonu św. Franciszka z Asyżu na ziemiach polskich w latach 1918-1939 w świetle czasopism tercjarskich, Bernardinum, Pelplin 2010, s. 151-152, 190, 199.

17 „Głos św. Franciszka” - wydawane przez Prowincję św. Jadwigi od 1908 r. pismo kierowane do tercjarzy III Zakonu św. Franciszka.

${ }^{18}$ M. KuczKowski, Tercjarze św. Franciszka z Asyżu, Bernardinum, Pelplin 2014.

${ }^{19}$ M. KuczKowski, Ks. Antoni Henryk Szuman - tercjarz franciszkański, „Głos św. Franciszka" 2010, nr 10, s. 38 .
} 
asyskiego, zatwierdzonej przez Stolicę Apostolską ${ }^{20}$. Trzeci Zakon franciszkański miał i ma nadal nie tylko prowadzić jednostki do życia doskonalszego, ale powinien również przyczynić się do odradzania społeczeństwa według ducha Ewangelii. Zakon ten od początku gromadził osoby różnych stanów i zawodów, które pragnęły żyć według nauki Kościoła katolickiego i dzielić się nią z innymi na wzór swojego założyciela, którego siła duchowa opierała się na miłości do Boga i stworzonego świata. Patriarcha asyski, który dał Trzeciemu Zakonowi nazwę „Bracia pokutujący”, jasno zaznaczył, że tercjarze winni się odznaczać przede wszystkim dwiema cnotami: miłością braterską i umiłowaniem pokuty. Członkowie Trzeciego Zakonu skupiali się w kongregacjach tercjarskich przy klasztorach, sanktuariach i parafiach ${ }^{21}$.

W Kodeksie Prawa Kanonicznego z roku 1917 w kan. 702 napisano, że „Trzeci Zakon Franciszkański był stowarzyszeniem ludzi świeckich, do którego mogli należeć księża diecezjalni, którego członkowie, zwani tercjarzami, starali się dążyć do doskonałości chrześcijańskiej pod kierunkiem i w duchu Pierwszego Zakonu Franciszkańskiego, kierując się regułą zatwierdzoną przez Stolicę Apostolską"22. Stąd do grona jego członków zaliczały się także osoby duchowne: papieże (m.in. Leon XIII, św. Pius X, Benedykt XI, Pius XI, Pius XII), arcybiskupi (np. nuncjusz papieski Francesco Marmaggi), biskupi (m.in. św. Józef Sebastian Pelczar, św. Zygmunt Szczęsny Feliński, Adam Stefan książę Sapieha) oraz księża diecezjalni (m.in. ks. Antoni Henryk Szuman, ks. Bernard Łosiński, ks. Konstantyn Krefft, ks. Antoni Arasmus) ${ }^{23}$. Ciekawy jest fakt, że wszyscy wymienieni tu kapłani diecezjalni są włączeni do grona Męczenników Polskich okresu II wojny światowej, we wspomnianym na początku artykułu procesie beatyfikacyjnym ${ }^{24}$. Kościół wyniósł na ołtarze już 129 osób, pochodzących z III Zakonu św. Franciszka z Asyżu ${ }^{25}$. Do tej grupy być może dołączy niedługo kolejny błogosławiony - ks. Antoni Henryk Szuman. Okres jego pracy duszpasterskiej był też zbieżny z najbardziej dynamicznym rozwojem Trzeciego Zakonu na ziemiach polskich w historii Zakonu.

${ }^{20}$ Zob. M. KucZKowski, Dzieje Trzeciego Zakonu, s. 33.

${ }^{21}$ J. BAR, Szkoła Seraficka, Drukarnia Archidiecezjalna, Wrocław 1948, s. 18-21.

22 J. BAR, Prawo zakonne po Soborze Watykańskim II, ATK, Warszawa 1977, s. 14; Tercjarska Reguła Życia z odpustami dla braci i Sióstr Pokutujacych św. O. Franciszka Serafickiego w III. Zakonie żyjących, Kraków 1934; Reguła i jej wyjaśnienie oraz świadectwo przyjęcia i profesji, Kraków 1928; Reguła Tercyarska, w: Nowy Brewiarzyk Tercyarski, Kraków 1910, s. 91-112.

${ }^{23}$ M. Kuczkowski, Dzieje Trzeciego Zakonu, s. 150-152.

${ }^{24}$ R. Szwoch, Nie ma miłości większej od tej, „Pielgrzym”19(2008), nr 18, s. 12-13.

${ }^{25}$ L. IRIARTE, Historia franciszkanizmu, Bracia Mniejsi Kapucyni, Kraków 1998, s. 570. 
W 1926 r. na 21 diecezji naszego kraju, najwięcej kongregacji tercjarskich znajdowało się w diecezji sandomierskiej (168), a pod względem liczby tercjarzy dominowały takie diecezje, jak: krakowska, podlaska i przemys$\mathrm{ka}^{26}$. W tym czasie Trzeci Zakon był już obecny w każdej diecezji polskiej.

\section{W KRĘGU RUCHU FRANCISZKAŃSKIEGO}

W diecezji chełmińskiej jedną $\mathrm{z}$ najstarszych kongregacji tercjarskich była wspólnota ze Starogardu Gdańskiego, która powstała w roku $1886^{27}$. Na podstawie opublikowanego w „Szkole Serafickiej”28 sprawozdania za 1932 r. wynika, że kongregacja w tym czasie liczyła 330 osób, a dyrektorem owego zgromadzenia był ks. Antoni Henryk Szuman, proboszcz parafii św. Mateusza $^{29}$. Pełniąc tę funkcję, kierował on zgodnie $\mathrm{z}$ udzieloną mu władzą całą kongregacją - był jej ojcem, kierownikiem i sędzią. Stał na straży karności i dyscypliny, a także troszczył się o wzrost liczby członków oraz o właściwą formację ${ }^{30}$. Należy tu zaznaczyć, że stanowisko dyrektora w tej kongregacji było tak samo zaszczytne jak i trudne. Generalnie funkcję dyrektora Trzeciego Zakonu mógł pełnić kapłan zakonny, lecz w przypadku znacznej odległości wspólnoty tercjarskiej od klasztoru franciszkańskiego i związanej z tym niemożności kierowania i „,nadzorowania na bieżąco”, funkcję tę mógł sprawować ksiądz diecezjalny. Nominacja dyrektora dokonywana była w sposób nieskrępowany od ordynariusza diecezji przez przełożonego zakonnego, natomiast w przypadku powołania na to stanowisko kapłana diecezjalnego, wymagana była zgoda ordynariusza miejsca. Wybór proboszcza starogardzkiego na ten urząd świadczył o predyspozycjach duszpasterskich oraz wielkim zaufaniu, jakim był on obdarzony przez biskupa, władze Pierwszego Zakonu i miejscowych tercjarzy. Jednak samo zaufanie nie stanowiło o wyborze. Od dyrektora wymagano bowiem też takich przymiotów, jak: mądrość, roztropność oraz oczywiście członkostwo w Trzecim Zakonie św. Franciszka. Kolejne warunki dotyczyły znajomości reguły i ceremoniału tercjarskiego,

\footnotetext{
${ }^{26}$ M. KucZKowski, Dzieje Trzeciego Zakonu, s. 158-159.

${ }^{27}$ M. Granowa, Kościerzyna, „Szkoła Seraficka” 12(1937), nr 3, s. 93.

${ }^{28}$ Jedno z 12 czasopism tercjarskich ukazujących się w Polsce w okresie międzywojennym (1918-1939).

${ }^{29}$ H. Szuman, Sprawozdanie Zgromadzenia III. Zakonu w Starogardzie za rok 1932, „Wiadomości Tercjarskie" 1933, nr 19, s. 238-239.

${ }^{30}$ M. Kuczkowski, Ks. Antoni Henryk Szuman, s. 38; TEnżE, Dzieje Trzeciego Zakonu św. Franciszka, s. 75; TENŻE, Tercjarze św. Franciszka, s. 203.
} 
a także innych przepisów związanych z tercjarstwem franciszkańskim. Według zaleceń, dyrektor miał charakteryzować się umiłowaniem Trzeciego Zakonu i posiadać świadomość, że życie duchem św. Franciszka z Asyżu jest wspaniałym środkiem do zbawienia. Ponadto oczekiwano od niego roztropności potrzebnej w czasie przyjmowania nowych członków, a także zaangażowania w pracy na rzecz odnowienia zaniedbanych kongregacji. Miał on także wykazywać się cierpliwością oraz wytrwałością w pokonywaniu przeciwności ${ }^{31}$. Ks. Szuman wywiązywał się z obowiązków dyrektora dobrze, o czym świadczy fakt, że w czasie, kiedy pełnił on ten urząd, kongregacja Trzeciego Zakonu zbierała się regularnie każdego miesiąca nie tylko na zebrania, ale również na nabożeństwa ${ }^{32}$.

Równie znaczącym wydarzeniem było wybranie pelplińskiego kandydata na ołtarze do Rady Głównej Delegatów Trzeciego Zakonu. Organ ten powoływany był do kierowania życiem tercjarskim w całej Polsce. Wybór został dokonany 16 czerwca 1937 roku w Krakowie na dorocznym zjeździe delegatów tejże organizacji, kiedy przypadało 700-lecie przybycia franciszkanów do Polski ${ }^{33}$. Ksiądz prałat przez trzy lata pełnił w Radzie funkcję delegata księży dyrektorów. Był on w niej jedynym kapłanem diecezjalnym, pozostali członkowie Rady byli kapłanami zakonnymi. Wybór ten świadczył o ,,wyjątkowości" ks. Szumana jako kapłana i tercjarza. Przedstawione wydarzenie potwierdzało kompetencje i dowodziło o wielkim zaufaniu, jakim był on darzony przez tercjarzy. Trzeci Zakon św. Franciszka tuż przed wybuchem drugiej wojny światowej liczył ponad 200000 członków ${ }^{34}$.

W ramach swojej posługi w Trzecim Zakonie, ks. Szuman był inicjatorem nie tylko licznych zebrań, obchodów czy nabożeństw, ale także za wzorem św. Franciszka asyskiego, urządzał wraz z tą wspólnotą „Gwiazdki” dla ubogich. Podczas ich trwania zaopatrywał on najbiedniejszych w artykuły żywnościowe ${ }^{35}$. Poza tym zainicjował on obchody jubileuszowe $\mathrm{z}$ okazji śmierci św. Antoniego oraz przedstawienia teatralne („Padre Antonio”, „Księżniczka Elżbieta na dworze św. Ludwika”) ${ }^{36}$.

Jak zostało to już wyżej wspomniane, pelpliński kandydat na ołtarze popularyzował ideę trzeźwościową również w prasie tercjarskiej. Najważniejszym

\footnotetext{
${ }^{31}$ M. Kuczkowski, Dzieje Trzeciego Zakonu św. Franciszka z Asyżu, s. 72-74.

${ }^{32}$ M. KuczKowski, Tercjarze św. Franciszka, s. 203.

${ }^{33}$ M. Kuczkowski, Dzieje Trzeciego Zakonu św. Franciszka z Asyżu, s. 190-191; TENŻE, Ks. Antoni Henryk Szuman, s. 39.

${ }^{34}$ M. KuczKowski, Ks. Antoni Henryk Szuman, s. 39.

${ }^{35}$ Tamże.

${ }^{36}$ Tenże, Tercjarze św. Franciszka, s. 203.
} 
artykułem dotyczącym tej tematyki był wykład przedstawiony w Krakowie, w dniach 20-21.06.1938 r. na Zjeździe Delegatów Zgromadzeń Tercjarskich w Polsce. Temat referatu brzmiał następująco: „Dlaczego i jak powinien tercjarz walczyć z alkoholizmem" ${ }^{37}$. Ks. Szuman, jako zagorzały wróg panującej w latach dwudziestolecia międzywojennego plagi alkoholizmu, zwalczał ją również w ramach swojej działalności w przestrzeni Trzeciego Zakonu. We wspomnianym referacie Sługa Boży opisał m.in. dane statystyczne dotyczące szerzącej się plagi, konsekwencje medyczne alkoholizmu oparte na naukowych badaniach, oficjalnej nauce Kościoła na ten temat, a także przedstawiał swoje własne poglądy ${ }^{38}$. W tekście tym możemy odnaleźć również takie słowa, skierowane do tercjarzy: „Skoro więc najwyższe władze kościelne tak bardzo popierają walkę zorganizowaną z wielkim wrogiem ludzkości, któremu na imię alkoholizm czyli nowoczesne pijaństwo społeczne, to chyba członkowie III Zakonu św. Franciszka, jako front katolicki, jako szermierze tak potrzebnej pokuty i umartwienia, jako bojownicy z wszelkim złem moralnym nie mogą przechodzić obojętnie koło tego palącego zagadnienia" ${ }^{39}$. W wygłoszonym referacie przypomniał, iż tercjarze są „braćmi i siostrami od Pokuty"40.

Reasumując te bardzo skąpe informacje dotyczące tercjarskiej działalności ks. prałata Antoniego Henryka Szumana należy stwierdzić, że kapłan ten w swojej pracy na rzecz franciszkańskiej wspólnoty był na pewno jednostką wybitną. Cieszył się zaufaniem przełożonych, a także innych członków Trzeciego Zakonu Franciszkańskiego. Wkładał on wiele trudu, aby zaufania, którym go obdarzono, nie zawieźć. Dowodem na to są liczne przedsięwzięcia, które w ramach Trzeciego Zakonu św. Franciszka były realizowane właśnie z inicjatywy pelplińskiego Sługi Bożego. Pokazują one również, że poza aktywną pracą na rzecz osieroconych dzieci oraz wielką batalią z narodowym problemem alkoholizmu, to właśnie działalność tercjarska jest trzecim wielkim dziełem księdza Antoniego Henryka Szumana. Właśnie ono powinno stanowić znaczący argument $\mathrm{w}$ procesie jego, oby jak najrychlejszej, beatyfikacji.

\footnotetext{
${ }^{37}$ H. Szuman, Dlaczego i jak powinien tercjarz walczyć z alkoholizmem, „Wiadomości Tercjarskie" 1938, nr 35, s. 346-353.

${ }^{38}$ K. Dalecki, Pelpliński Stuga Boży Antonii Henryk Szuman, s. 105-107.

${ }^{39}$ H. Szuman, Dlaczego i jak powinien, s. 346.

${ }^{40}$ L. IRIARTE, Historia franciszkanizmu, s. 570.
} 


\section{BIBLIOGRAFIA}

BAR J., Prawo zakonne po Soborze Watykańskim II, ATK, Warszawa 1977.

BAR J., Szkoła Seraficka, Drukarnia Archidiecezjalna, Wrocław 1948.

DALeCKi K., Pelpliński Stuga Boży Antoni Henryk Szuman i jego walka na polu spolecznego problemu alkoholizmu w okresie lat międzywojennych, „Studia Pelplińskie” 52(2018), s. 95-109.

DĄBRowski K., Ksiądz prałat Henryk Antoni Szuman życie i działalność, „Studia Pelplińskie” 11(1976), s. 43-55.

GŁodowsKi B., O ruchu trzeźwościowym $w$ diecezji chetmińskiej w latach 1848-1939, Instytut Kaszubski, Gdańsk 2016.

Granowa M., Kościerzyna, „Szkoła Seraficka” 12(1937), nr 3, s. 93.

IRIARTE L., Historia franciszkanizmu, Bracia Mniejsi Kapucyni, Kraków 1998.

KrasiŃSKA I., Działalność redakcyjno-wychowawcza ks. Henryka Antoniego Szumana na rzecz najmłodszych odbiorców. Na przykładzie „Naszego Przewodnika” (1913-1919), w: Działalność instytucji wydawniczych na rzecz oświaty i edukacji w XIX $i$ XX wieku, red. I. Michalska, G. Michalski, Wydawnictwo Uniwersytetu Łódzkiego, Łódź 2014, s. 299-318.

Kuczkowski M., Dzieje Trzeciego Zakonu św. Franciszka z Asyżu na ziemiach polskich w latach 1918-1939 w świetle czasopism tercjarskich, Bernardinum, Pelplin 2010.

Kuczkowski M., Ks. Antoni Henryk Szuman - tercjarz franciszkański, „Głos św. Franciszka” 2010, nr 10, s. 38-39.

Kuczkowski M., Tercjarze św. Franciszka z Asyżu, Bernardinum, Pelplin 2014.

Mazurowski W., Ksiadz Antoni Henryk Szuman ze Starogardu Gdańskiego, „Pielgrzym” 15 (2004), nr 12, s. 9.

Mross H., Stownik biograficzny kapłanów diecezji chetmińskiej wyświęconych w latach 18211920, Bernardinum, Pelplin 1995, s. 324-325.

Reguła i jej wyjaśnienie oraz świadectwo przyjęcia i profesji, Kraków 1928.

Reguła Tercyarska, w: Nowy Brewiarzyk Tercyarski, Kraków 1910, s. 91-112.

SAJEWICZ J., Głos maja sieroty. Życie i działalność wielkiego opiekuna sierot ks. prałata Antoniego Henryka Szumana proboszcza starogardzkiego zamordowanego w Fordonie w 1939 r., Veritas, Londyn 1985.

Szuman H., Dlaczego i jak powinien tercjarz walczyć z alkoholizmem, „Wiadomości Tercjarskie” 1938, nr 35, s. 346-353.

Szuman H., Sprawozdanie Zgromadzenia III. Zakonu w Starogardzie za rok 1932, „Wiadomości Tercjarskie" 1933, nr 19, s. 238-239.

Szwoch R., Stuga Boży, ks. prałat Antoni Henryk Szuman, „Męczennicy. Biuletyn Informacyjny Postulacji Procesu Beatyfikacyjnego II Grupy Polskich Męczenników z okresu II wojny światowej" 2004, nr 1, s. 13-18.

Szwoch R., Nie ma miłości większej od tej, „Pielgrzym” 19(2008), nr 18, s. 12-13.

Tercjarska Reguła Życia z odpustami dla Braci i Sióstr Pokutujących św. O. Franciszka Serafickiego w III. Zakonie żyjacych, Kraków 1934.

TheIss W., Pomorskie Towarzystwo Opieki Nad Dziećmi (1918-1948). Zarys działalności, „Kultura i Edukacja" 4(1994), s. 63-76. 
THEISS W., Społeczno-wychowawcza działalność ks. Henryka Szumana, w: Katolicka a liberalna myśl wychowawcza w Polsce w latach 1918-1939, red. E. Walewander, Towarzystwo Naukowe KUL, Lublin 2000.

TheISs W., Troska i nadzieja. Działalność społeczno-wychowawcza ks. Henryka Szumana na Pomorzu w latach 1908-1939, Wydawnictwo Adam Marszałek, Toruń 2012.

Theiss W., Pomorskie Towarzystwo Opieki Nad Dziećmi 1918-1948, „Rozprawy z Dziejów Oświaty" 36(1994), s. 173-191.

Walkusz J., Duchowieństwo katolickie diecezji chełmińskiej 1918-1939, Wydawnictwo Diecezjalne, Pelplin 1992.

Walkusz J., Pozaduszpasterska działalność ks. Antoniego Henryka Szumana, „Męczennicy. Biuletyn Informacyjny Postulacji Procesu Beatyfikacyjnego II Grupy Polskich Męczenników z okresu II wojny światowej” 2004, nr 1, s. 19-25.

https://ekai.pl/pelplin-maja-zakonczenie-etapu-polskiego-procesu-beatyfikacyjnego-ii-grupy-meczenn ikow-ii-wojny-swiatowej/ (20.10.2019).

\section{SŁUGA BOŻY ANTONI HENRYK SZUMAN - TERCJARZ FRANCISZKANSSKI}

\section{STRESZCZENIE}

Artykuł poświęcony jest postaci ks. prałata Antoniego Henryka Szumana, który przewodniczy II grupie męczenników Diecezji Pelplińskiej, z okresu II wojny światowej, w trwającym obecnie procesie beatyfikacyjnym. Tekst jest próbą zarysowania, do tej pory jeszcze najmniej znanej aktywności tego kapłana, a mianowicie jego pracy w ramach Trzeciego Zakonu św. Franciszka z Asyżu. Najpierw nakreślony został tu bardzo ogólnie stan tercjarstwa w Polsce oraz jego działalność. Następnie opisane zostały funkcje i przedsięwzięcia realizowane w tym zgromadzeniu przez pelplińskiego Sługę Bożego.

Słowa kluczowe: diecezja pelplińska; II grupa polskich męczenników; proces beatyfikacyjny; Szuman; Trzeci Zakon św. Franciszka. 